\title{
Cryopreservation of Synchytrium solstitiale In Planta
}

\author{
T. L. Widmer, Research Plant Pathologist, European Biological Control Laboratory, United States Department of \\ Agriculture-Agricultural Research Service, Campus International de Baillarguet, CS 90013, Montferrier sur Lez, \\ 34988 St. Gely du Fesc CEDEX, France
}

\begin{abstract}
Widmer, T. L. 2006. Cryopreservation of Synchytrium solstitiale in planta. Plant Dis. 90:429432 .

The fungus Synchytrium solstitiale is a candidate for use as a biocontrol agent against Centaurea solstitialis. This obligate parasite can be propagated only in planta, which necessitates development of a method for preserving cultures for longer periods of time for routine biological studies and shipment to other laboratories. Normally, sporangia embedded within the plant tissue release zoospores when submersed in water at temperatures above freezing. To examine what chemicals might inhibit zoospore release, infected tissue was exposed to different suspensions of fungicides. Cycloheximide and benomyl completely inhibited zoospore release or immediately induced encystment from tissue stored in these two chemicals, respectively. A few zoospores were released in suspensions of iprodione and propionic acid but were not motile. However, when tissue stored in iprodione or propionic acid was transferred to fresh distilled water, abundant active zoospores were released. Freezing the infected tissue at different temperatures in different cryoprotectants also affected the release of motile zoospores. Infected $C$. solstitialis tissue was immersed in water, water plus iprodione, methanol, ethylene glycol, dimethyl sulfoxide, glycerol, skim milk, trehalose, or sucrose and subjected to different temperatures for various periods of time. Some treatments protected the viability of the fungus for a shorter period of time whereas other treatments completely inhibited release. The best results were obtained when infected tissue was stored at $-2^{\circ} \mathrm{C}$ in $0.5 \mathrm{M}$ sucrose where active zoospores were released after 12 weeks of storage. Overall, results obtained from this study demonstrate a technique for longterm storage of $S$. solstitiale.
\end{abstract}

Additional keywords: biological control, weed, yellow starthistle

A new fungus, Synchytrium solstitiale Widmer (Chytridiales), was described as a pathogen of Centaurea solstitialis, yellow starthistle, in France (16). This fungus is being investigated as a candidate for use as a biocontrol agent against this invasive weed in the United States. The fungus is an obligate parasite and cannot be cultured on artificial media. It survives in planta under field conditions on the rosette stage of the plant, normally from November through April. During the life cycle, it develops bright orange sporangia grouped together in sori that release zoospores. The motile zoospores then are able to infect new seedlings. Previous work has shown that zoospore release occurs optimally between 5 and $15^{\circ} \mathrm{C}(17)$.

Sporangia of the fungus do not persist through the summer months and cannot be found in plant tissue after the plant starts to bolt and loses its rosette leaves; hence, the

Corresponding author: T. L. Widmer

E-mail: tlwidmer@ars-ebcl.org

Accepted for publication 4 October 2005.

DOI: 10.1094/PD-90-0429

This article is in the public domain and not copyrightable. It may be freely reprinted with customary crediting of the source. The American Phytopathological Society, 2006. necessity to find a storage method. The fungus can be propagated on seedlings under artificial conditions (17), but this method requires a lot of attention as well as space to maintain the plants under specific conditions. The seedlings require constant moisture at temperatures of 5 to $20^{\circ} \mathrm{C}$ and high sporangial production per seedling is not easily achieved. Thus, the purpose of this study was to investigate a way to maintain the viability of the fungus for longer periods of time so that routine biological studies can be conducted when the infected tissue cannot be collected from the field.

\section{MATERIALS AND METHODS}

Fungal material. S. solstitiale was collected from naturally infected $C$. solstitialis leaves in a field near Cazevieille, France. The leaf material was surface sterilized by immersing the leaves in $50 \mathrm{ml}$ of $75 \%$ ethanol plus two drops of Tween 20 (Sigma-Aldrich, Saint Quentin Fallavier, France) for $30 \mathrm{~s}$. The leaves were transferred to $0.5 \%$ calcium hypochlorite for 20 min and then rinsed three times in sterile distilled water for $10 \mathrm{~min}$ each time. The leaves were blotted with a paper towel to remove any excess water and placed in an enclosed petri plate containing a moist paper towel at $5^{\circ} \mathrm{C}$ until needed, but not for more than 2 weeks.
Zoospore release in various solutions. Infected leaf segments approximately equal in size $\left(6\right.$ to $\left.10 \mathrm{~mm}^{2}\right)$ and in concentration of sori were cut from the same leaf. Two infected segments were placed in an individual well in a 12-well packet containing $0.5 \mathrm{ml}$ of water plus streptomycin $(100 \mathrm{mg} / \mathrm{liter})$, skim milk $(0.1,0.25,0.5$, or $1.0 \%)$, methanol $(10 \%)$, glycerol $(10$ or $25 \%$ ), ethylene glycol (10 or $25 \%$ ), or dimethyl sulfoxide (DMSO; 10 or $25 \%$ ). The plastic wells were covered with a lid and placed in an incubator in the dark at $10^{\circ} \mathrm{C}$. After $24 \mathrm{~h}$, released zoospores were observed for motility with a compound microscope at $\times 200$. The experiment was repeated twice with different plants collected at different times.

Exposure of fungus to fungicides. Infected leaf segments approximately equal in size $\left(6\right.$ to $\left.10 \mathrm{~mm}^{2}\right)$ and in concentration of sori were cut from the same leaf. Two infected segments were placed in an individual well in a 12-well packet containing $0.5 \mathrm{ml}$ of water plus streptomycin (100 $\mathrm{mg} / \mathrm{liter})$, cycloheximide $(10,25$, or 100 $\mathrm{mg} / \mathrm{liter})$, benomyl $(5,10,25$, or 50 $\mathrm{mg} /$ liter $)$, iprodione $(5,10$, or $25 \mathrm{mg} / \mathrm{liter})$, mancozeb ( 5 or $10 \mathrm{mg} /$ liter), or propionic acid $(10 \mathrm{mg} / \mathrm{liter})$. The plastic wells were covered with a lid and placed in an incubator in the dark at $5^{\circ} \mathrm{C}$. After $24 \mathrm{~h}$, released zoospores were observed for motility with a compound microscope at $\times 200$. The segments then were removed from the suspensions of fungicides, rinsed three times in sterile distilled water, immersed in $0.5 \mathrm{ml}$ of water plus streptomycin (100 mg/liter), and placed in an incubator at $10^{\circ} \mathrm{C}$. After $24 \mathrm{~h}$, released zoospores were observed for motility with a compound microscope at $\times 200$. The experiment was repeated twice with different plants collected at different times.

Impact of cryoprotectants on zoospore release. Solutions of DMSO (10 and $25 \%)$, methanol $(10 \%)$, sucrose $(0.5 \mathrm{M})$, trehalose (10\%), glycerol (10 and 25\%), ethylene glycol (10 and 25\%), and water with a suspension of iprodione (10 $\mathrm{mg} /$ liter) plus streptomycin (100 mg/liter) were prepared and dispensed $(1 \mathrm{ml})$ into $2.5-\mathrm{ml}$ glass, screwcap vials. Infected leaf segments approximately equal in size (6 to $10 \mathrm{~mm}^{2}$ ) and in concentration of sori were placed in each of the glass vials containing the cryoprotectant. The glass vials were stored at $5^{\circ} \mathrm{C}$. After various lengths of time ( $1 \mathrm{~h}$ or $1,6,14$, or 30 days), the segments were removed from the cryoprotectant, 
rinsed three times in sterile distilled water, immersed in $0.5 \mathrm{ml}$ of distilled water plus streptomycin (100 mg/liter), and placed in an incubator at $10^{\circ} \mathrm{C}$. After $24 \mathrm{~h}$, released zoospores were observed for motility with a compound microscope at $\times 200$. The experiment was repeated twice with different plants collected at different times.

Cryoprotectants and temperature effects on zoospore release. Solutions of sterile distilled water plus streptomycin (100 mg/liter), water plus streptomycin (100 mg/liter) and iprodione (10 mg/liter), DMSO (5, 10, and 25\%), methanol (1, 5, and $10 \%)$, sucrose $(0.5 \mathrm{M})$, trehalose (10 and $40 \%)$, glycerol (10 and $15 \%)$, skim milk $(8.5,10$, and 25\%), and ethylene glycol $(5 \%)$ were prepared and dispensed (1 $\mathrm{ml}$ ) into $2.5-\mathrm{ml}$ glass, screwcap vials. Infected leaf segments approximately equal in size $\left(20\right.$ to $\left.30 \mathrm{~mm}^{2}\right)$ were placed in each of the glass vials containing the cryoprotectant. The vials were frozen directly either in liquid nitrogen; in a freezer at $-80,-20,-10$, or $-2^{\circ} \mathrm{C}$; or under three different temperature sequences: (i) in succession for $1 \mathrm{~h}$ each at -20 and $-80^{\circ} \mathrm{C}$ and then in liquid nitrogen; (ii) in succession for $1 \mathrm{~h}$ each at -20 and then $-80^{\circ} \mathrm{C}$; or (iii) in succession for $1 \mathrm{~h}$ each at $-80^{\circ} \mathrm{C}$ and then liquid nitrogen. After 1, 4, or 30 days or 8 or 12 weeks, the vials were removed from the freezers and thawed quickly in a $45^{\circ} \mathrm{C}$ water bath. The tissue segments were removed from the cryoprotectant, rinsed three times in sterile distilled water, transferred to a plastic well containing $0.5 \mathrm{ml}$ of distilled water plus streptomycin (100 mg/liter), and placed in an incubator at $15^{\circ} \mathrm{C}$. After $24 \mathrm{~h}$, released zoospores were observed for motility with a compound microscope at $\times 200$. The experiment was repeated three times with different plants collected at different times.

Impact of storage on zoospore pathogenicity. Active zoospores released from tissue stored at various temperatures and cryoprotectants were tested for their ability to infect tissue. Tissue stored in vials for

Table 1. Synchytrium solstitiale zoospore release after $24 \mathrm{~h}$ in solutions of cryoprotectants at $5^{\circ} \mathrm{C}$

\begin{tabular}{lc}
\hline Cryoprotectant & Active zoospores $^{\mathbf{a}}$ \\
\hline Water & + \\
$0.1 \%$ skim milk & + \\
$0.25 \%$ skim milk & + \\
$0.5 \%$ skim milk & + \\
$1 \%$ skim milk & + \\
$0.5 \mathrm{M}$ sucrose & - \\
$10 \%$ methanol & - \\
$10 \%$ glycerol & - \\
$25 \%$ glycerol & - \\
$10 \%$ ethylene glycol & - \\
$25 \%$ ethylene glycol & - \\
$10 \%$ DMSO & - \\
$25 \%$ DMSO & - \\
\hline${ }^{\mathrm{a}}$ Presence (+) or absence (-) of active zoo- \\
spores.
\end{tabular}

30 days in water at $-2^{\circ} \mathrm{C}$, water plus streptomycin $(100 \mathrm{mg} /$ liter $)$ and iprodione (10 $\mathrm{mg} /$ liter) at $-2^{\circ} \mathrm{C}, 0.5 \mathrm{M}$ sucrose at -2 and $-10^{\circ} \mathrm{C}$, and $1 \%$ methanol at $-2^{\circ} \mathrm{C}$ were removed from the freezer and thawed quickly in a $45^{\circ} \mathrm{C}$ water bath. The tissue segments were removed from the cryoprotectant, rinsed three times in sterile distilled water, and transferred to a glass well containing $0.5 \mathrm{ml}$ of distilled water plus streptomycin (100 mg/liter). Five 10-dayold yellow starthistle seedlings were placed in the glass well containing active zoospores so that the apical meristem tissue and cotyledons were slightly immersed in the suspension. The glass wells were put in a covered petri dish and placed in an incubator at $15^{\circ} \mathrm{C}$. After $24 \mathrm{~h}$, the seedlings were removed and planted in plastic pots containing autoclaved vermiculite. Water was misted on the planted seedlings with a hand sprayer and the top of the cup was covered with a clear plastic lid to retain moisture. The seedlings were placed in an incubator at $15^{\circ} \mathrm{C}$ with a 16 -h photoperiod and $11^{\circ} \mathrm{C}$ with an 8 -h dark period. The plants were misted every 2 days. Symptoms were observed after 10 days. The experiment was repeated once.

\section{RESULTS}

Zoospore release in various solutions. Infected tissue released abundant, motile zoospores in water and skim milk dilutions after $24 \mathrm{~h}$ at $10^{\circ} \mathrm{C}$ (Table 1). Most of the zoospores released were active (data not shown). No zoospores were released in any of the different dilutions of methanol, glycerol, ethylene glycol, sucrose, or DMSO. Results from all three replications were the same.

Exposure of fungus to fungicides. Motile zoospores were released only in solutions of benomyl at 5 and $10 \mathrm{mg} / \mathrm{liter}$ (Table 2); however, the numbers were minimal compared with the release in water alone (data not shown). Release of zoo- spores occurred in the cycloheximide $(5$ $\mathrm{mg} / \mathrm{liter})$, benomyl $(5,10,25$, and 50 $\mathrm{mg} / \mathrm{liter})$, iprodione $(5,10,25 \mathrm{mg} / \mathrm{liter})$, mancozeb (5 and $10 \mathrm{mg} / \mathrm{liter}$ ), and propionic acid (10 mg/liter) suspensions, but were not motile (data not shown). After the $S$. solstitiale-infected tissue had been rinsed in water, active zoospores were released in iprodione $(5,10$, and 25 $\mathrm{mg} /$ liter concentrations) and propionic acid (10 mg/liter concentration). Cycloheximide, benomyl, and mancozeb were fungicidal after $24 \mathrm{~h}$ of exposure when the tissue was rinsed in water and immersed in water plus streptomycin. Results from all three replications were the same.

Impact of cryoprotectants on zoospore release. Different chemicals for use as cryoprotectants gave various results when exposed over time at $5^{\circ} \mathrm{C}$ (Table 3 ). The cryoprotectant that still permitted release of active zoospores from the immersed tissue for the longest time (14 days) was iprodione at $10 \mathrm{mg} /$ liter plus streptomycin at $100 \mathrm{mg} / \mathrm{liter}$. Tissue exposed to $10 \%$ DMSO and $0.5 \mathrm{M}$ sucrose released zoospores after 6 days of storage at $5^{\circ} \mathrm{C}$. After this time period, the tissue became degraded or was infected with secondary fungi. The other cryoprotectants tested inhibited active zoospore release after 1 day in storage. Tissue stored in several treatments $(10 \%$ methanol after 6 days and $10 \%$ trehalose after 1 or 6 days) released zoospores, but no motility was observed (data not shown). Results from all three repeats of the experiment were the same.

Cryoprotectant and temperature effects on zoospore release. Infected tissue released motile zoospores after being immersed in distilled water, distilled water plus iprodione, $10 \%$ skim milk, $0.5 \mathrm{M}$ sucrose, $1 \%$ methanol, $5 \%$ methanol, $10 \%$ trehalose, or 5\% ethylene glycol for 4 days at -10 or $-2^{\circ} \mathrm{C}$ (Table 4). After 30 days at $-2^{\circ} \mathrm{C}$, active zoospores were released from

Table 2. Fungicide effect on Synchytrium solstitiale zoospore release and movement after storage for $24 \mathrm{~h}$ at $5^{\circ} \mathrm{C}$

\begin{tabular}{lccc}
\hline Fungicide & Concentration (mg/liter) & Initial release $^{\mathbf{a}}$ & Rinsed tissue $^{\mathbf{b}}$ \\
\hline None & - & + & + \\
Cycloheximide & 100 & - & - \\
Cycloheximide & 25 & - & - \\
Cycloheximide & 10 & - & - \\
Cycloheximide & 5 & - & - \\
Benomyl & 50 & - & - \\
Benomyl & 25 & - & - \\
Benomyl & 10 & + & - \\
Benomyl & 5 & + & + \\
Iprodione & 25 & - & + \\
Iprodione & 10 & - & + \\
Iprodione & 5 & - & - \\
Mancozeb & 10 & - & - \\
Mancozeb & 5 & - & + \\
Propionic acid & 10 & - & \\
\hline
\end{tabular}

${ }^{a}$ Release of active zoospores (+) in the fungicide solution after $24 \mathrm{~h}$ at $5^{\circ} \mathrm{C}$.

${ }^{\mathrm{b}}$ Release of active zoospores (+) after $24 \mathrm{~h}$ at $10^{\circ} \mathrm{C}$ from tissue that was exposed to the fungicide solution for $24 \mathrm{~h}$ and then rinsed four times in sterile distilled water before being immersed in water plus streptomycin (100 mg/liter). 
infected tissue when stored in $0.5 \mathrm{M}$ sucrose, $1 \%$ methanol, distilled water, and distilled water plus iprodione, but only 0.5 $\mathrm{M}$ sucrose released active zoospores after 30 days at $-10^{\circ} \mathrm{C}, 8$ weeks at -2 and $-10^{\circ} \mathrm{C}$, and 12 weeks at $-2^{\circ} \mathrm{C}$. None of the cryoprotectants tested were able to preserve the fungus viability (release of active zoospores) when frozen at $-20^{\circ} \mathrm{C}$ or below. This includes the fungus subjected to the three different temperature sequences. It was due to this observation (that no survival was observed in the extremely low temperatures) that later tests involving some of the cryoprotectants did not include temperatures below $-10^{\circ} \mathrm{C}$. The number of zoospores released from the sporangia stored in $0.5 \mathrm{M}$ sucrose after being frozen at $-10^{\circ} \mathrm{C}$ for 8 weeks was low compared with samples frozen at $-2^{\circ} \mathrm{C}$ for the same time period (data not shown). Likewise, active zoospores released after 12 weeks at $-2^{\circ} \mathrm{C}$ also were very low. Results from all four replications were the same.

Impact of storage on zoospore pathogenicity. No impact of freezing tissues was observed on the infectivity of the zoospores released from frozen sporangia in planta (data not shown). All of the yellow starthistle seedlings exposed to the released zoospores showed typical orange galls resulting from infection after 10 days. Both experiments showed the same results.

\section{DISCUSSION}

The long-term storage of obligate parasites is always a challenge. Yellow starthistle-infected tissue can be stored at $5^{\circ} \mathrm{C}$ in petri plates; however, the tissue starts to degrade after 1 to 2 weeks. The primary purpose of this study was to develop a method to preserve $S$. solstitiale in a viable form for a longer period of time than 2 weeks. The majority of techniques for long-term preservation of fungi have involved freezing at very low temperatures (liquid nitrogen) or lyophilization (12). Cryoprotectants such as DMSO, methanol, sucrose, trehalose, glycerol, and ethylene glycol have been used successfully in the past to store fungi, bacteria, and plant cells $(3,5,6,9)$. Methods to freeze obligate parasites such as downy mildew sporangia have been successful; however, only germination of the sporangia was assessed for viability and not release of zoospores $(7,14,15)$. For $S$. solstitiale, no mycelium is produced; therefore, active zoospore release is the only method that can be used to test the survival and viability of the fungus. Because the majority of previous fungal storage studies froze samples in liquid nitrogen or at $-80^{\circ} \mathrm{C}$, these techniques were tried first with $S$. solstitiale. However, attempts to freeze yellow starthistle tissue infected with $S$. solstitiale at low temperatures (below $-20^{\circ} \mathrm{C}$ ) in some early trials and maintain viability were unsuccessful, regardless of the cryoprotectant used. Therefore, it was necessary to try to preserve the tissue at higher temperatures without promoting zoospore release; therefore, low temperatures were not included in some later trials. This lack of success with low-temperature storage has been observed with other fungi as well (5).

Synchytrium-infected yellow starthistle tissue cannot be stored in water at temperatures above freezing because zoospores will release within $24 \mathrm{~h}$. Attempts to store the infected tissue in solutions with various additives at $5^{\circ} \mathrm{C}$ over longer periods of time without inducing zoospore release were not successful. At this temperature, secondary fungi contaminated the solutions over time, even though the tissue was surface sterilized, or the additives completely inhibited release even when the tissue was rinsed in sterile water. Thus, it was necessary to test the effect of certain fungicides that may inhibit zoospore release but prevent the growth of secondary fungi. Iprodione, benomyl, mancozeb, and cycloheximide were chosen because they represent different classes of fungicides with different modes of action that are known to have effects on inhibiting the growth of various fungi. Propionic acid was selected because it has been used as a safe food preservative that is known to inhibit microbe growth rather than kill microbe cells (13). The goal of this part of the study was to place $S$. solstitiale in a stasis, as well as inhibit the growth of secondary fungi, until the chemical could be washed out and $S$. solstitiale revived to release zoospores. Iprodione and propionic acid initially inhibited zoospore release into the suspensions; however, when rinsed free of the chemical, numerous active zoospores were released. Most of the infected tissue stored in the various fungicide suspensions (except higher concentrations of cycloheximide) released some zoospores that either encysted or became nonmotile immediately after release, because an attached flagellum still was observed in many cases. However, based upon a previous study (17), active zoospores are needed for infection to occur; therefore, these nonmotile zoospores or cysts are irrelevant for disease incidence. At the concentrations of iprodione and propionic acid tested, Synchytrium-infected tissue remained viable for zoospore release after exposure to these chemicals; thus, they had the potential to be used as storage agents. Storage at $5^{\circ} \mathrm{C}$ in a suspension of iprodione plus streptomycin was possible for up to 2 weeks; however, at that time, the yellow starthistle tissue started to degrade. After 4 weeks, there was no zoospore release. Freezing tissue at $-2^{\circ} \mathrm{C}$ in the solution of iprodione plus streptomycin did not increase the storage time that the fungus was

Table 3. Effect of storing Synchytrium solstitiale-infected tissue in cryoprotectants at $5^{\circ} \mathrm{C}$ for various lengths of time on release of motile zoospores ${ }^{\mathrm{a}}$

\begin{tabular}{lccccc}
\hline & \multicolumn{5}{c}{ Time } \\
\cline { 2 - 6 } Cryoprotectant & $\mathbf{1 ~ h}$ & $\mathbf{1}$ day & $\mathbf{6}$ days & $\mathbf{1 4}$ days & $\mathbf{3 0}$ days \\
\hline $10 \%$ DMSO & + & + & + & - & DNT \\
$25 \%$ DMSO & + & + & - & DNT & DNT \\
$10 \%$ methanol & + & + & - & - & DNT \\
0.5 M sucrose & + & + & + & - & DNT \\
$10 \%$ trehalose & + & - & - & - & DNT \\
$10 \%$ glycerol & + & - & - & - & DNT \\
$25 \%$ glycerol & - & - & DNT & DNT & DNT \\
$10 \%$ ethylene glycol & + & + & - & - & DNT \\
$25 \%$ ethylene glycol & + & - & DNT & DNT & DNT \\
Iprodione at $10 \mathrm{mg} /$ liter + & & & & & \\
streptomycin at $100 \mathrm{mg} /$ liter & + & + & + & + & -
\end{tabular}

${ }^{a}$ Time of Synchytrium solstitiale-infected Centaurea solstitialis tissue exposed to cryoprotectants at $5^{\circ} \mathrm{C}$. Presence $(+)$ or absence $(-)$ of motile zoospores. DMSO $=$ dimethyl sulfoxide and DNT $=$ did not test.

Table 4. Maximum length of storage time in selected cryoprotectants at various temperatures at which active zoospores were observed released from Synchytrium solstitiale-infected Centaurea solstitialis tissue $^{\mathrm{a}}$

\begin{tabular}{|c|c|c|c|c|c|}
\hline Cryoprotectant & Liquid $\mathrm{N}_{2}$ & $-80^{\circ} \mathrm{C}$ & $-20^{\circ} \mathrm{C}$ & $-10^{\circ} \mathrm{C}$ & $-2^{\circ} \mathrm{C}$ \\
\hline None & 0 & 0 & 0 & 0 & 0 \\
\hline Water & 0 & 0 & 0 & 4 days & 30 days \\
\hline Water + microbials $^{\mathrm{b}}$ & DNT & DNT & DNT & 4 days & 30 days \\
\hline $10 \%$ skim milk & DNT & DNT & DNT & 4 days & 4 days \\
\hline $1 \%$ methanol & DNT & DNT & DNT & 4 days & 30 days \\
\hline $5 \%$ methanol & DNT & DNT & DNT & 4 days & 4 days \\
\hline $10 \%$ trehalose & DNT & DNT & DNT & 4 days & 4 days \\
\hline $5 \%$ ethylene glycol & DNT & DNT & DNT & 4 days & 4 days \\
\hline $0.5 \mathrm{M}$ sucrose & 0 & 0 & 0 & 8 weeks & 12 weeks \\
\hline
\end{tabular}

a Tissue was thawed, rinsed three times in sterile distilled water, and observed for zoospore release and motility after $24 \mathrm{~h}$ at $10^{\circ} \mathrm{C}$. DNT $=$ did not test.

b Streptomycin (100 mg/liter) and iprodione (10 mg/liter). 
viable. Although $S$. solstitiale-infected tissue immersed at $5^{\circ} \mathrm{C}$ in $0.5 \mathrm{M}$ sucrose did not release motile zoospores past 6 days, freezing at $-2^{\circ} \mathrm{C}$ in $0.5 \mathrm{M}$ sucrose gave the best results in this study. The fungus remained viable under these conditions for up to 12 weeks.

Sucrose and trehalose have been used successfully as a cryoprotectant in various plant and tissue culture systems (2,3). Sucrose also has been used in formulations to preserve bacteria and fungi that are proposed as biological control organisms $(1,18)$. Sucrose has been demonstrated to protect liposomes, isolated biological membranes, and some intact cells $(4,11)$. It has been suggested that sucrose protects lipopolysaccharides on the cell surface of Escherichia coli against freezing injury (10). In a previous study, trehalose was more effective in preserving the viability of bacteria than sucrose (8); however, in the current study, sucrose proved more consistently effective in preservation of $S$. solstitiale than trehalose (Table 4). Further work could be conducted using an electron microscope to study the impact of freezing at different temperatures and to determine how sucrose protects the fungus, which might lead to a more efficient method for preservation.

The purpose of this study was to test various cryoprotectants and develop a procedure of storing this fungus for longer periods of time. Although there was some variability observed in the number of motile zoospores released between the different storage conditions (data not shown), the numbers were not quantified because it is not known how many zoospores are needed to infect and produce visible symptoms on the plant. This study will need to be conducted to understand the epidemiology of this fungus.

Thus, these results enable studies to continue during the summer months when the fungus is no longer available to be collected in the field and without maintaining it on living tissue, which requires considerable time and space. A period of storage time longer than the 12 weeks obtained in this study would be desirable. This would provide not only more flexibility in continued research on this organism but also a method for maintaining a viable isolate in a culture collection.

\section{LITERATURE CITED}

1. Amsellem, Z., Zidack, N. K., Quimby, P. C., Jr., and Gressel, J. 1999. Long-term dry preservation of viable mycelia of two mycoherbicidal organisms. Crop Prot. 18:643649.

2. Bhandal, I. S., Hauptmann, R. M., and Widholm, J. M. 1985. Trehalose as cryoprotectant for the freeze preservation of carrot and tobacco cells. Plant Physiol. 78:430-432.

3. Burch, J., and Wilkinson, T. 2000. Cryopreservation of protonemata of Ditrichum cornubicum (Patan) comparing the effectiveness of four cryoprotectant treatments. CryoLetters 23:197-203.

4. Crowe, J. H., Crow, L. M., Carpenter, J. F., and Aurell Winstrom, C. 1987. Stabilization of dry phospholipid bilayers and proteins by sugars. Biochem. J. 242:1-10.

5. Dahmen, H., Staub, T., and Schwinn, F. J. 1983. Technique for long-term preservation of phytopathogenic fungi in liquid nitrogen. Phytopathology 73:241-246.

6. Finkle, B. J., and Ulrich, J. M. 1979. Effects of cryoprotectants in combination on the survival of frozen sugarcane cells. Plant Physiol. 63:598-604.

7. Gulya, T. J., Masirevic, S., and Thomas, C. E. 1993. Preservation of air-dried downy mildew sporangia in liquid nitrogen without cryopro- tectants or controlled freezing. Mycol. Res. 97:240-244.

8. Leslie, S. B., Israeli, E., Lighthart, B., Crowe, J. H., and Crowe, L. M. 1995. Trehalose and sucrose protect both membranes and proteins in intact bacteria during drying. Appl. Environ. Microbiol. 61:3592-3597.

9. Mycock, D. 1999. Addition of calcium and magnesium to glycerol and sucrose cryoprotectant solution improves the quality of plant embryo recovery from cryostorage. CryoLetters 20:77-82.

10. Ray, B., Souzu, H., and Speck, M. L. 1975. Cryoprotection of Escherichia coli by the penetrating and nonpenetrating cryopreservatives. Cryobiology 12:553.

11. Rudolf, A. S., and Crowe, J. H. 1985. Membrane stabilization during freezing: the role of two natural cryoprotectants, trehalose and proline. Cryobiology 22:367-377.

12. Simione, F. P., and Brown, E. M. 1991. ATCC Preservation Methods: Freezing and FreezeDrying, 2nd ed. American Type Culture Collection, Rockville, MD.

13. Stratford, M., and Anslow, P. A. 1996. Comparison of the inhibitory action on Saccharomyces cerevisiae of weak-acid preservatives, uncouplers, and medium-chain fatty acids. FEMS Microbiol. Lett. 142:53-58

14. Tetsuka, Y., and Katsuya, K. 1983. Storage of sporangia of hop and vine downy mildews in liquid nitrogen. Ann. Phytopathol. Soc. Jpn. 49:731-735.

15. Viranyi, F. 1985. A simple technique for longterm storage of Plasmopara halstedii sporangia at low temperature. Trans. Br. Mycol. Soc. 85:529-531.

16. Widmer T. L. 2004. Synchytrium solstitiale sp. nov. causing a false rust on Centaurea solstitialis in France. Mycologia 96:407-410.

17. Widmer, T. L., and Guermache, F. 2006. Factors affecting infection of yellow starthistle (Centaurea solstitialis) by Synchytrium solstitiale, causal agent of false rust disease. Plant Dis. 90:425-428.

18. Zidack, N. K., and Quimby, P. C., Jr. 2002. Formulation of bacteria for biological weed control using the stabilize method. Biocontrol Sci. Technol. 12:67-74. 